questioning what the medical establishment considers its gold standard for evaluating treatment.

PAUL KNIPSCHILD Professor of epidemiology

University of Limburg,

Department of Epidemiology,

$6200 \mathrm{MD}$ Maastricht,

The Netherlands
1 McGourty H. How to evaluate complementary therapies. A literature review. Liverpool: Liverpool Public Health Observatory, 1993. (Report No 13.)

2 Anthony HM. Some methodological problems in the assessment of complementary therapy. In: Lewith GT, Aldridge D, eds. Clinical research methodology for complementary therapies. London: Hodder and Stoughton, 1993:108-21.

3 Miettinen OS. Theory of medicine: at the core of post-Flexnerian education in medicine. Amsterdam: Free University Press, 1987

4 Knipschild P, Leffers P, Feinstein AR. The qualification period. 3 Clin Epidemiol 1991;44:461-4.

5 Feinstein AR. Hard science, soft data and the challenge of choosing clinical variables in research. Clin Pharmacol Ther 1977;22:485-98.

\title{
How can doctors diagnose colorectal cancer earlier?
}

\section{By increasing patients' awareness of the disease and investigating them promptly when they present}

The life time risk of death from colorectal cancer in England and Wales is about 1 in 50, rising rapidly after the age of 50. With more than 17000 deaths a year ${ }^{1}$ colorectal cancer is the second commonest cause of death from cancer. The results of treatment remain disappointing: five year survival is less than $40 \%$ and this has not changed for 30 years. ${ }^{2}$

The prognosis of the disease is closely related to the stage of the tumour at presentation. Of those patients with Dukes's type A tumours (confined to the bowel wall), more than $90 \%$ survive long term; the figure in those with lymph node disease is $30 \% .^{2}$ Currently, only 1 in 10 excised colorectal malignancies are Dukes's type A lesions. ${ }^{3}$ As operative mortality for elective surgery is less than $10 \%$ and adjuvant treatment has yet to make any substantial impact, earlier diagnosis offers the only hope for improved survival.

The population can be divided into groups at average and high risk of colorectal cancer. Mass population screening for faecal occult blood detects $56 \%-78 \%$ of asymptomatic colorectal carcinomas. ${ }^{4-6}$ Malignancies diagnosed in this way tend to be less advanced than cancers in an unscreened population. ${ }^{4}$ Uptake of screening, however, is often disappointing: in the largest British trial just over half the patients completed the screening test. ${ }^{4}$ To date, only one controlled trial has shown that annual screening for faecal occult blood significantly reduces mortality from colorectal cancer. ${ }^{7}$

If the case for mass screening has not yet been proved, who should be investigated and how? Patients with a genetic predisposition to colorectal cancer, adenomatous polyps, previous colorectal carcinoma, or ulcerative colitis affecting the whole colon for more than 10 years are all at higher risk of colorectal cancer. Between $5 \%$ and $10 \%$ of all colorectal cancers are associated with autosomal dominant conditions (such as familial adenomatous polyposis and Lynch syndromes types I and II). ${ }^{8}$ Family history, DNA probe analysis, dental screening, and ophthalmic testing can identify patients at risk. This approach is currently being evaluated. ${ }^{9}$ The establishment of a regional register for familial adenomatous polyposis in the west midlands has resulted in a significant reduction in the mean age at diagnosis in patients affected by the condition and in the incidence of colorectal cancer. ${ }^{10}$ This service should be established nationwide.

For patients with adenomatous colorectal polyps most gastroenterologists follow the recommendation of the King's Fund consensus panel. ${ }^{11}$ This is to perform colonoscopy and remove symptomatic polyps larger than $5 \mathrm{~mm}$, and repeating colonoscopy every three to five years. A similar policy may be justified for patients with colorectal carcinoma because of the $2-5 \%$ risk of subsequent new (metachronous) carcinoma. ${ }^{12}{ }^{13}$ Although patients with longstanding ulcerative colitis affecting the whole colon make up a small proportion of patients who develop colorectal cancer, careful surveillance with barium enema examination or colonoscopy and biopsy enables cancer to be diagnosed when cure is likely. ${ }^{14}$ (The cost in terms of medical resources, however, is high.)

All patients presenting to their general practitioner with gastrointestinal symptoms should have a family history taken and an abdominal and rectal examination performed. Evidence exists that these are frequently neglected in patients subsequently shown to have a colorectal cancer. Testing for occult blood is not recommended in the community for determining which symptomatic patients to refer because of its low specificity and sensitivity. ${ }^{11} 15$

Nearly half of all colorectal cancers originate in the rectum and are within reach of a rigid sigmoidoscope. As few general practitioners perform sigmoidoscopy and open access barium enema examination is not generally available symptomatic patients require investigation in hospital. Open access sigmoidoscopy has been evaluated: although popular and well used, it led to only a modest improvement in the detection of early colorectal cancers. ${ }^{16}$ Sigmoidoscopy is a straightforward skill to acquire: hopefully the likelihood of payment for sigmoidoscopy will increase the estimated $10 \%$ of general practices that own and use a sigmoidoscope.

Above all, we should raise the awareness of colorectal cancer and encourage symptomatic patients to present earlier, investigating them appropriately and promptly when they do so.

IAN MACLENNAN Consultant general surgeon

JAMES HILL

Manchester Royal Infirmary, Senior registrar in surgery

Manchester, M13 9WL

1 Office of Population Censuses and Surveys. Death by sex, cause and quarter (England, Wales and abroad) 1991. London: HMSO, 1991.

Office of Population Censuses and Surveys. Cancer statistics: incidence, survival and mortality in England and Wales. London: HMSO, 1981. (Studies on medical and population subjects No 43.)

Phillips RKS, Hittinger R, Fry JS, Fielding LP. Malignant bowel obstruction. Br $\mathcal{J}$ Surg 1985;72:296-302.

4 Hardcastle JD, Chamberlain J, Thomas WM, Pye G, Sheffield J, James PD, et al. Randomised controlled trial of faecal occult blood screening for colorectal cancer. Lancet 1989;i:1160-4.

5 Kewenter J, Bjork S, Haglind E, Smith L, Svanvik J, Ahren C. Screening and rescreening for colorectal cancer. A controlled trial of faecal occult blood testing in 27700 patients. Cancer 1988;62:645-51.

6 Kronberg O, Fenger C, Sondergaard O, Pedeson KM, Olsen J. Initial mass screening for colorectal cancer with faecal occult blood test. Scand $\mathcal{F}$ Gastroenterol 1987;22:677-86.

7 Mandel JS, Bond JH, Church TR, Snover DC, Bradley GM, Schuman LM, et al. Reducing mortality from colorectal cancer by screening for fecal occult blood. $N$ Engl $\mathcal{F}$ Med 1993;328: 1365-71.

8 Lynch HT, Lanspa SJ, Boman BM. Hereditary non polyposis colorectal cancer-Lynch syndromes I and II. Gastroenterol Clin North Am 1988;17:679-712.

9 Houlston RS, Murday V, Harocopos C, Williams CB, Slack J. Screening and genetic counselling for relatives of patients with colorectal cancer in a family based study. $B M \mathcal{Y} 1990 ; 301: 366-8$.

10 Morton DG, MacDonald F, Haydon J, Cullen R, Barker G, Hulten M, et al. Screening practice for familial adenomatous polyposis: the potential for regional registers. Br $₹$ Surg 1993;80:255-8. King's Fund Forum. Cancer of the colon and rectum. Br f Surg 1990;77:1063-5.

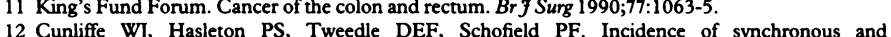
metachronous colorectal carcinoma. Br J Surg 1984;71:941-3.
mante

13 Luchtefeld MA, Ross DS, Zander JD, Folse JR. Late development of metachronous colorectal cancer. Dis Colon Rectum 1987;30:180-4.

14 Lennard-Jones JE, Morson BC, Ritchie JK, Williams CB. Cancer surveillance in ulcerative colitis. Lancet 1983;ii:149-53.

15 Leicester RJ, Lightfoot A, Millar J, Collin-Jones DG, Hunt RH. Accuracy and value of Hemoccult test in symptomatic patients. $B M \mathcal{F}^{1983 ; 286: 672-3 .}$

16 Donald IP, Fitzgerald Frazer JS, Wilkinson SP. Sigmoidoscopy/proctoscopy service with open access to general practitioners. BMY 1985;290:759-61. 